\title{
Seasonal patterns in the South African share index futures market
}

\author{
G. Watson \& E. vd M. Smit* \\ Graduate School of Business, University of Stellenbosch, P.O. Box 610, Bellville 7535, Republic of South Africa
}

Received July 1994

\begin{abstract}
In this article three near futures contracts are examined, namely the All Share Near Future, the All Industrial Near Future and the All Gold Near Future, to determine whether daily futures returns exhibit well-documented seasonal patterns. The detection of seasonal patterns in the daily returns for the three underlying indices, namely the All Share Index, the All Industrial Index and the All Gold Index, is also included. Results are compared to the findings of Hattingh \& Smit. It is shown that seasonal similarities exist between the futures market and the spot market. Seasonal phenomena in the underlying indices further tend to remain stable over the different sample periods considered.
\end{abstract}

In die artikel word ondersoek ingestel na drie termynkontrakte, naamlik die Alle Aandele-nabytermynkontrak, die Nywerheidsaandele-nabytermynkontrak en die Alle Goudaandele-nabytermynkontrak om te bepaal of daaglikse opbrengste op termynkontrakte gedokumenteerde seisoenale patrone volg. Die identifisering van seisoenale patrone in die drie onderliggende indekse, naamlik die Algehele Aandele-indeks, die Nywerheidsaandele-indeks en die Goudaandeleindeks word ook ingesluit. Resultate word vergelyk met die bevindinge van Hattingh \& Smit. Daar word aangetoon dat daar seisoenale ooreenkomste tussen die termynmarkte en die mark vir die onderliggende instrumente bestaan. Seisoenale verskynsels in die onderliggende indekse neig om stabiel te bly oor verskillende steekproefperiodes onder oorweging.

*Author to whom correspondence should be addressed.

\section{Introduction}

Research aimed at establishing seasonal patterns in financial markets is typical of efforts to expose trading rules which will negate the efficient markets hypothesis. Internationally convincing empirical evidence has been provided to support seasonal effects in both the equity and bond markets.

Equity returns tend to be low on Mondays and high on Wednesdays and Fridays (day-of-the-week effect), high at the turn of the year (turn-of-the-year effect) and high in January (the January effect). Evidence of a turn-of-the-month effect exists, in that daily returns are higher during the last day of a month and first four trading days of the next month compared to the daily returns during the rest of the month. A week-of-the-month effect, where equities exhibit their highest returns in the first week and their lowest returns in week three, has also been detected. In South Africa evidence of a day-of-the-week, turn-of-the-month and turn-of-the-year effect for some of the most popular indices on the Johannesburg Stock Exchange has also recently been established while the analysis of bond data has also shown that day-ofthe-week, week-of-the-month and turn-of-the-month effects are present in South African financial markets (Hattingh \& Smit, 1993).

The current research extends that of Hattingh \& Smit (1993) by examining three near futures contracts, namely the All Share Near Future, the All Industrial Near Future and the All Gold Near Future contracts for seasonal patterns. An investigation into seasonal patterns in the daily returns of the three underlying indices, namely the All Share Index, the All Industrial Index and the All Gold Index is also conducted to determine whether seasonal patterns in futures contracts are just reflections of seasonalities in the underlying spot market. Of course, futures and spot prices are linked by strict theoretical relationships. However, pricing inefficiencies may cause these relationships to break down, leading to different seasonal patterns. (See Snell \& Smit, 1990) for evidence of inef- ficient pricing behaviour in the South African futures market.)

If seasonal patterns exist, it would be possible for portfolio managers to make abnormal profits by altering trading patterns. However, investment decisions are also governed by factors such as the availability of funds, amounts available, portfolio composition and the level of economic and political stability. For the individual too it would be possible to make abnormal returns if a strict investment strategy based on seasonal patterns is followed. Transaction costs may, however, neutralize this possibility.

A study of daily price movements in the South African futures market is conducted over the period 1988 to 1993 with the purpose of establishing whether the following seasonal patterns are present, namely the:

- day-of-the-week effect;

- week-of-the-month effect;

- month-of-the-year effect;

- turn-of-the-month effect;

- turn-of-the-year effect; and

- January versus other non-turn-of-the-month days effect.

The article is structured as follows: the next section provides a literature survey, followed by an exposition of the data and research methods. Subsequent sections deal with the results and conclusions.

\section{Literature survey}

While a number of reasons for seasonal behaviour in financial markets have been proposed and rejected, an encompassing theory is still absent and the persistence of seasonalities and different patterns in different markets are not well understood. Research proceeds inductively rather than deductively as different markets and instruments are analyzed to establish the universality of documented patterns.

Weekly seasonals in share returns, manifesting as less than average returns on Mondays, have been well documented for international capital markets (see e.g. French, 1980; Gibbons 
\& Hess, 1981; Lakonishok \& Levi, 1982; and Keim \& Stambaugh, 1984). Rogalski (1984) calls this a week-end effect and argues that the negative returns on Monday occur between Friday's market closure and the opening on Monday. Similar phenomena have been documented by Jaffee \& Westerfield (1985), Smirlock \& Starks (1986) and Harris (1986) who demonstrates that the week-end effect relates to firm size. Connolly $(1989,1991)$ casts doubt on the statistical significance of the day-of-the-week effect using sophisticated statistical correction methods. Chang, Pinegar \& Ravichandran (1993) support the views of Connolly $(1989,1991)$ as regards the U.S. markets, but document significant weekly seasonals in seven European countries as well as Canada and Hong Kong. French (1980) examines two alternate models of the process generating share returns. Under a calendar time hypothesis returns are expected to be three times higher on Mondays than on other days of the week. Under the trading time hypothesis, returns were expected to be equal for each day of the week. In search of an explanation, French (1980) also examines returns of days following holidays and concludes that the negative average returns found on Mondays are due to some weekend effect rather than a general closedmarket effect. He states that perhaps the most obvious explanation of why returns tend to be low on Mondays is that information released on weekends tend to be unfavourable. In fear of 'panic selling' announcements are delayed until weekends to allow more time for information to digest. While this is certainly possible, it does not explain the systematic patterns in an efficient market, where prices will be discounted to take such weekend information into account.

Rozeff \& Kinney (1976) show convincing evidence of seasonality in monthly share returns on the New York Stock exchange, of which an outstanding feature is the fact that January produces unusually high mean rates of return - the socalled January-effect. This effect is related to firm-size by Reinganum (1983). He finds that the January effect for small firms is significant regardless of whether the firms are subject to tax-loss selling. The tax-loss hypothesis assumes that shares whose prices decreased during the year would be subject to selling pressure towards the end of the year. Prices are depressed during the year and rebound at the beginning of January. He concludes that although potential tax-loss selling may explain extraordinary returns witnessed during January, it does not seem capable of explaining the entire anomalous return behaviour of small firms in January. Small firms least likely to be sold for tax reasons also exhibit large average January returns. Ariel (1987) finds a week-of-the-month effect by showing that if a trading month is divided in half, the mean daily return for the first half significantly exceeds that of the second half. He proposes that an examination of economic announcements which occur disproportionately in the first or last half of the month may lead to an explanation of why share returns for the first half of the trading month significantly exceed that of the second half. Pettengill \& Jordan (1988) document a significant turn-of-the-month effect. For both large and small firms over half of the total monthly returns occur on the last and first three trading days of each month.

The main body of the research on seasonality in capital markets is based on share markets, but Jordan \& Jordan
(1991) test for seasonal patterns in long term corporate bond returns using the Dow Jones Composite Bond Average. The Standard and Poor 500 Index and an equally weighted index based on the companies in the Dow Jones Composite Bond Average are used to compare differences in seasonal patterns between bond and share returns. They find that long term corporate bonds display significant turn-of-the-year and weekof-the-month effects. Daily share returns on the Standard and Poor Index display a significant day-of-the-week and turn-ofthe-month effect, and a less significant week-of-the-month effect. With the exception of the week-of-the-month effect, the results for the bond index and the Standard and Poor 500 Index are mirror images in that the effects significant for one are not significant for the other. The equally weighted index shows similar patterns to that of the Standard and Poor 500 Index, except that it also displays a turn-of-the-year effect. Recently, Hattingh \& Smit (1993) have examined the seasonal patterns in daily price movements of the Post Office, Eskom 168 and RSA bonds, comparing these with the patterns in three share indices. In contrast with international findings, it is shown that seasonal similarities exist between the bond and share markets.

As regards futures markets, Chiang \& Tapley (1983) document a Monday effect for a variety of futures contracts. Cornell (1985) and Dyl \& Maberly (1986) find that share index futures returns exhibit weekend-effects similar to that documented for the underlying securities. Gay \& Kim (1987) find a negative Monday seasonal in commodity futures indices, which is supported by Chang \& Kim (1988) in an independent study based on different commodity price and futures indices. For both of these latter studies, however, all evidence of a Monday-effect has disappeared in the futures data by 1982. In the financial futures markets, Johnston, Kracaw \& McConnell (1991) examine daily returns on GNMA, T-bond, T-note and T-bill futures contracts. They find a negative Monday seasonal for the GNMA and T-bond contracts, while a positive Tuesday seasonal is present in GNMA, T-bond and Tnote contracts.

In South Africa Bhana (1985) shows the existence of a Monday-effect and tests the calendar time and trading time hypotheses using daily returns associated with the Rand Daily Mail 100 Industrial Index and the Johannesburg Stock Exchange Actuaries Index during the period 1978 through to 1983. Neither the trading time nor the calendar time hypothesis offer an explanation of the distribution of returns over the different days of the week. He argues that the release of unfavourable information on weekends as an explanation for the results will only be valid in an inefficient market. In efficient markets Friday's closing prices will fully reflect the anticipated release of unfavourable information. Furthermore, he states that the trading pattern on the Johannesburg Stock Exchange is heavily influenced by the overall international investment trends. The closure of the markets on weekends creates uncertainty on the Johannesburg Stock Exchange for share transactions on Mondays. Share transactions on Mondays are expected to be minimal. Thus the uncertainty in the market on Mondays, coupled with the involvement of the staff of institutional investors in administration relating to the balancing of books for settlement on Tuesdays, is likely to delay the execution of share transactions. 
Bradfield (1990) demonstrates the absence of a Januaryeffect and states that issues such as thin and lacklustre trading on smaller markets may have an influence on the variability of the outcome of tests on these small markets. He argues that thin and lacklustre trading is characteristic of December, which is traditionally the holiday season in South Africa, and that this impacts on the volatility of shares over this month. He concludes that the seasonal effect found in December is more likely to be a result of relatively less volatility than substantial returns in December.

\section{Data and research method}

The raw data consists of daily observations of the closing prices of three near futures contracts, namely the All Share Near Future, the All Industrial Near Future and the All Gold Near Future. The daily price series for each type of contract has been constructed by using the futures contract nearest to delivery. A non-overlapping price series for each type of contract is thus obtained.

To compare differences in seasonal patterns between the near futures contracts and the indices on which they are based, seasonal effects in daily returns for the underlying indices, namely the All Share Index, the All Industrial Index and the All Gold Index, are included in the study. The notion that seasonal patterns in futures contracts are reflections of seasonal patterns in the underlying indices can then be examined. Because the period over which the analysis is conducted differs from that used by Hattingh \& Smit (1993), a direct comparison can be made for each of the seasonal patterns investigated. This will be useful in analyzing whether seasonal patterns are period bound, although a degree of time series overlap has to be acknowledged.

The sample period for each of the six sets of data used in the study is 4 January 1988 to 20 April 1993. Each seasonal pattern is investigated separately over this period. If the closing price or index was not available on any given day or if no trading took place on the day, the previous available closing price was used.

For each type of contract the daily returns are computed from index to index on consecutive trading days. This is similar to the method used by Jordan \& Jordan (1991), namely that:

$R_{t}=\left(B l_{t}-B l_{t-1}\right) / B l_{t-1}$

where

$R_{\mathrm{f}}=$ the return on the index for day $\mathrm{t}$;

$B l_{t}=$ the value of the index at the end of day $t$; and

$B l_{t-1}=$ the value of the index at the end of day $t-1$.

For each seasonal effect the daily returns are grouped according to the seasonal pattern being investigated. This is done for each set of data analysed.

To establish whether a day-of-the-week effect exists, each daily return is classified according to its day of the week. The hypothesis that the mean daily returns are equal across different days of the week is then examined.

To investigate a week-of-the-month effect daily returns are classified into one of four weeks in a month. The first ten trading days of each month will be classified as days $+1,+2$, $\ldots,+10$ and the last ten trading days of each month as days $-10,-9 \ldots,-1$. The first trading week in a month will consist of days +1 to +5 , the second contains +6 to +10 , the third -10 to -6 and the last contains -5 to -1 . In months with more than 20 trading days some days will be omitted and in others some days may have to be counted twice. This will only be done with tests involving the week-of-the-month effect. The hypothesis that mean daily returns are equal across different weeks of the month is then examined.

To establish whether a month-of-the-year effect (also known as the January effect) exists, each daily return is classified according to its month of the year. The hypothesis that the mean daily returns are equal across different months of the year is then tested.

To find out whether a turn-of-the-month effect exists, daily returns are classified into two groups: turn-of-the-month days and non-turn-of-the-month days. The turn of the month is defined as the first four trading days in each month plus the last trading day of the previous month. The hypothesis that the mean daily return for turn-of-the-month days is equal to that of non-turn-of-the-month days is then investigated.

In order to establish whether a turn-of-the-year effect exists, daily returns are classified into two groups: turn-ofthe-year days and other turn-of-the-month days. The last trading day in December and the first four trading days in January are defined as turn-of-the-year days. The hypothesis that the mean daily return for turn-of-the-year days is equal to that of other turn-of-the-month days is then tested.

Lastly, to establish whether January returns are abnormally large beyond the turn of the year, the turn-of-the-month days are deleted in each month. Non-turn-of-the-month daily returns are then classified into two groups: January non-turnof-the-month days and other non-turn-of-the-month days. The hypothesis that the mean daily return for January non-turn-ofthe-month days is equal to that of other non-turn-of-themonth days is then tested.

One-way analysis of variance (ANOVA) F-tests, as part of the Statgraphics version 5.0 computer package, is used to analyse the sorted data. The one-way ANOVA procedure analyses the effect of one qualitative factor on one response variable and tests the hypothesis that the sample means are equal. One of the assumptions underlying the test is that the sample is drawn from a population which is normally distributed. Another is the equality of variances across groups.

For each seasonal pattern investigated a set of summary statistics is prepared. These include coefficients of skewness and kurtosis and standardized values of these coefficients. Due to limited space, these values are not repeated here, but are available from the authors on request.

When there is no reason to assume normality or homogeneity of the variances of the populations under consideration, the non-parametric Kruskal-Wallis test is used to replace the one-way analysis of variance F-test. The Kruskal-Wallis test statistic is therefore included in each of the investigations performed. In both the ANOVA F-test and the Kruskal-Wallis test a 5\% significance level is used to determine whether a statistically significant seasonal pattern exists.

In all of the analyses performed, the values of the standardized coefficients of skewness and kurtosis indicate significant deviations from a normal distribution and/or the standard deviations of different groups diverged widely. Overall the 
Table 1 Day-of-the-week effect test results

\begin{tabular}{lllll}
\hline & & & \multicolumn{2}{c}{ p-value* } \\
\cline { 4 - 5 } Index & Highest return & Lowest return & F-test & KW-test \\
\hline All Share Near Future & Thursday $(0.00230)$ & Monday $(-0,00042$ & 0.1371 & $0.0256^{*}$ \\
All Share Index & Wednesday $(0.00140)$ & Monday $(-0.00092)$ & $0.0312^{*}$ & $0.0272^{*}$ \\
All Industrial Near Future & Tuesday $(0.00195)$ & Friday $(-0.00048)$ & 0.0820 & $0.0348^{*}$ \\
All Industrial Index & Tuesday $(0.00170)$ & Monday $(-0.00114)$ & $0.0003^{*}$ & $0.0006^{*}$ \\
All Gold Near Future & Wednesday $(0.00064)$ & Monday $(-0.00047)$ & 0.9827 & 0,8824 \\
All Gold Index & Wednesday $(0.00104)$ & Friday $(-0.00078)$ & 0.8819 & 0.7286 \\
\hline * Significant at the 5\% level of significance. & & & \\
\hline
\end{tabular}

Table 2 Week-of-the-month effect test results

\begin{tabular}{lllll}
\hline & & & \multicolumn{2}{c}{ p.value* } \\
\cline { 4 - 5 } Index & Highest return & Lowest return & F-test & KW-test \\
\hline All Share Near Future & Week 1 (0.00236) & Week 2 (-0.001 1 1) & $0.0068^{*}$ & $0.0163^{*}$ \\
All Share Index & Week I (0.00218) & Week 2 (-0.00070) & $0.0019^{*}$ & $0.0024^{*}$ \\
All Industrial Near Future & Week 1 (0.00195) & Week 3 (-0.00006) & 0.0910 & 0.1259 \\
All Industrial Index & Week I (0.00191) & Week 3 (0.00023) & $0.0366^{*}$ & 0.0866 \\
All Gold Near Future & Week I (0.00184) & Week 2 (-0.00284) & 0.0685 & $0.0243^{*}$ \\
All Gold Index & Week I (0.00233) & Week 2 (-0.00225) & $0348^{*}$ & $0.0354^{*}$ \\
\hline *Significant at the 5\% level of significance & & & \\
\hline
\end{tabular}

results of the F-tests are under suspicion and reliance have been placed on the Kruskal-Wallis values.

\section{Summary of results}

\section{Day-of-the-week effect}

The day-of-the-week test results are summarized in Table 1. The All Share Near Future and All Share Index show a significant day-of-the-week effect with a highest mean return on Thursday and a lowest mean return on Monday (the All Share Index highest mean return is on Wednesday but differs from that of Thursday by only 1.4 basis points). For both sets of data Monday and Friday are the only days yielding a negative average daily return.

The All Industrial Near Future and All Industrial Index also show a significant day-of-the-week effect with a highest mean return on Tuesday. The lowest mean returns for both sets of data occur on Mondays and Fridays, with Mondays always giving rise to negative average returns. The All Gold Near Future and All Gold Index do not show a significant day-of-the-week effect.

For the day-of-the-week effect the patterns present in the indices are reflected in the futures contracts in that if significant results are obtained for the indices they are also obtained for the futures contracts. Highest and lowest mean daily returns between the indices and the corresponding futures contracts are also largely similar. The results obtained for the three indices are similar to those obtained by Hattingh \& Smit (1993) in some respects, especially as regard the presence of the Monday effect.

\section{Week-of-the-month effect}

The week-of-the-month results are summarized in Table 2. The All Share Near Future and All Share Index show a significant week-of-the-month effect with a highest mean return in week 1 and a lowest mean return in week 2 . For both sets of data higher returns are obtained in week 1 and week 4 with week 2 and week 3 yielding lower mean daily returns.

The All Industrial Near Future and All Industrial Index show a similar seasonal pattern to that of the All Share Near Future and All Share Index in that their highest mean returns occur in week 1 and week 4 and their lowest mean returns in week 2 and week 3 . The results, however, are not significant at the 5\% significance level (the All Industrial Near Future is significant at the $12.58 \%$ level and All Industrial Index is significant at the $8.60 \%$ level).

The All Gold Near Future and All Gold Index show a significant week-of-the-month effect with a highest mean return in week 1 and a lowest mean return in week 2 . For both sets of data negative mean returns are obtained in week 2 .

For the week-of-the-month effect the patterns present in the indices are reflected in the futures contracts in that if significant results are obtained for the indices they are also obtained for the futures contracts.

Highest and lowest mean daily returns between the indices and the corresponding futures contracts for the different weeks are also similar.

The results obtained for indices differ from those of Hatting \& Smit (1993) in that a significant week-of-the-month effect was found for the All Share Index and the All Gold Index. The observed patterns, however, closely mimic those of the earlier study. 
Table 3 Month-of-the-year effect test results

\begin{tabular}{lllcc}
\hline & & & \multicolumn{2}{c}{ p.value* } \\
\cline { 4 - 5 } Index & Highest return & Lowest return & F-test & KW-test \\
\hline All Share Near Future & March $(0.00252)$ & August $(-0.00131)$ & 0.5419 & 0.8163 \\
All Share Index & dMarch $(0.00243)$ & August $(-0.00161)$ & 0.2886 & 0.3842 \\
All Industrial Near Future & December $(0.00283)$ & September $(-0.00095)$ & 0.7619 & 0.7413 \\
All Industrial Index & December (0.00255) & August (-0.00058 & 0.1943 & 0.1923 \\
All Gold Near Future & March (0.00343) & August (-0.00366) & 0.5975 & 0.7490 \\
All Gold Index & March (0.00219) & August (-0.00299) & 0.6874 & 0.5540 \\
\hline *Significant at the 5\% level of significance & & & \\
\hline
\end{tabular}

\section{Month-of-the-year effect}

The month-of-the-year results are summarized in Table 3. The All Share Near Future and All Share Index show a definite seasonal pattern in that the highest mean daily returns occur in March and their lowest in August. For both sets of data April, August and September are the only months where a negative average daily return is found.

The All Industrial Near Future and All Industrial Index show a similar seasonal pattern to that of the All Share Near Future and All Share Index in that April, August and September are the only months where a negative mean daily return is found. The All Industrial Near Future and All Industrial Index highest mean daily returns occur in December and their lowest mean returns in September and August respectively.

The All Gold Near Future and All Gold Index show a similar seasonal pattern to that of the All Share Near Future and All Share Index in that their highest mean returns occur in March and their lowest in August. For the All Gold Near Future and the All Gold Index negative mean daily returns occur in similar months, namely January, February, April, August, October and December.

For the month-of-the-year effect the patterns present in the indices are largely reflected in the futures contracts in that highest and lowest mean returns occur in similar months, however none of the results are significant.

The patterns obtained for indices in this study differ from those of Hattingh \& Smit (1993) in that highest and lowest mean returns now occur in different months, but as in the earlier study, no significant effects are indicated.

\section{Turn-of-the-month effect}

The turn-of-the-month results are summarized in Table 4. The groups of data show similar seasonal patterns in that the turnof-the-month (TOM) days show higher returns when compared to the non-turn-of-the-month days for each set of data. The mean daily returns for the turn-of-the-month days range from 13.4 to 21.3 basis points, whereas the mean daily returns for the non-turn-of-the-month days range from -5.4 to 5.7 basis points.

The All Share Near Future and All Share Index show a significant turn-of-the-month effect. The All Industrial Index shows a significant turn-of-the-month effect, but the All Industrial Near Future turn-of-the-month effect is only significant at the 5.34\% significance level. The All Gold Near Future and All Gold Index do not show a significant turn-ofthe-month effect.

For the turn-of-the-month effect the patterns present in the indices are reflected in the futures contracts in that if significant results are obtained for the indices they are also obtained for the futures contracts, except for the All Industrial Near Future where the results are only significant at the $5.34 \%$ significance level.

The results obtained for indices in this study only differ from those of Hattingh \& Smit (1993) in that the All Industrial Index now shows a significant turn-of-the-month effect.

\section{Turn-of-the-year effect}

The turn-of-the-year results are summarized in Table 5. The groups of data show similar seasonal patterns in that the turnof-the-year (TOY) days show higher returns when compared to the other turn-of-the-month on daily returns for the days (January turn-of-month days excluded) for each set of data.

Table 4 Turn-of-month (TOM) effect test results

\begin{tabular}{lllll}
\hline & & & \multicolumn{2}{c}{ p.value* } \\
\cline { 3 - 5 } Index & Higher return & Lower return & F-test & KW-test \\
\hline All Share Near Future & TOM days $(0.00190)$ & non-TOM days $(0.00020)$ & $0.0434^{*}$ & $0.0193^{*}$ \\
All Share Index & TOM days (0.00213) & non-TOM days $(0.00007)$ & $0.0015^{*}$ & $0.0017^{*}$ \\
All Industrial Near Future & TOM days (0.00186) & non-TOM days $(0.00057)$ & 0.0963 & 0.0535 \\
All Industrial Index & TOM days (0.00193) & non-TOM days $(0.00053)$ & $0.0092^{*}$ & 0.0124 \\
All Gold Near Future & TOM days (0.00134) & non-TOM days (-0.00039) & 0.2542 & 0.1247 \\
All Gold Index & TOM days (0.00154) & non-TOM days (-0.00054) & 0.1250 & 0.0905 \\
\hline *Significant at the 5\% level of significance & & & \\
\hline
\end{tabular}


Table 5 Turn-of-the-year (TOY) effect test results

\begin{tabular}{llllc}
\hline & & & \multicolumn{2}{c}{ p.value* } \\
\cline { 5 - 5 } Index & Higher return & Lower return & F-test & KW-test \\
\hline All Share Near Future & TOYdays $(0.00600)$ & TOM days $(0.00149)$ & 0.0644 & 0.1516 \\
All Share Index & TOY days $(0.00527)$ & TOM days $(0.00182)$ & 0.0507 & 0.0568 \\
All Industrial Near Future & TOY days $(0.00692)$ & TOM days $(0.00136)$ & $0.0122^{*}$ & $0.0410^{*}$ \\
All Industrial Index & TOYdays $(0.00706)$ & TOM days $(0.00142)$ & 0.0001 & $0.0017^{*}$ \\
All Gold Near Future & TOYdays $(0.00511)$ & TOM days $(0.00097)$ & 0.3177 & 0.3802 \\
All Gold Index & TOY days $(0.00427)$ & TOM days $(0.00127)$ & 0.4364 & 0.5917 \\
\hline *Significant at the 5\% level of significance & & &
\end{tabular}

Table 6 January versus other non-turn-of-the-month days effect results

\begin{tabular}{lllll}
\hline & & & \multicolumn{2}{c}{ p-value* } \\
Index & Highest return & Lowest return & F-test & KW-test \\
\hline All Share Near Future & Other days (0.00035) & January (-0.00125) & 0.2640 & 0.2289 \\
All Share Index & Other days (0.00014) & January (-0.00063) & 0.4974 & 0.2463 \\
All Industrial Near Future & Other days (0.00067) & January (-0.00039) & 0.4361 & 0.2122 \\
All Industrial Index & Other days (0.00056) & January (0.00024) & 0.7387 & 0.5138 \\
All Gold Near Future & Other days (-0.00012) & January (-0.00296) & 0.2787 & 0.7339 \\
All Gold Index & Other days (-0.00041) & January (-0.00173) & 0.5770 & 0.5938 \\
\hline *Significant at the 5\% level of significance & & & \\
\hline
\end{tabular}

The mean daily returns for the turn-of-the-year days range from 42.7 to 70.6 basis points, whereas the mean daily returns for the other turn-of-the-month days range from 9.7 to 18.2 basis points.

The All Industrial Near Future and All Industrial Index show a significant turn-of-the-year effect. The All Share Near Future, All Share Index, All Gold Near Future and All Gold Index did not show a significant turn-of-the-year effect.

For the turn-of-the-year effect the patterns present in the indices are reflected in the futures contracts in that if significant results are obtained for the indices they are also obtained for the futures contracts.

The results obtained for indices in this study differ from those of Hattingh \& Smit (1993) only in so far the All Share Index only shows a significant turn-of-the-year effect at the $5.68 \%$ significance level, whereas in the earlier study it was significant.

January versus other non-turn-of-the-month days effect The January versus other non-turn-of-the-month days results are summarized in Table 6. The groups of data show similar seasonal patterns in that the January non-turn-of-the-month days show lower returns when compared to the other nonturn-of-the-month days for each set of data. The mean daily returns for the January non-turn-of-the-month days range from -29.6 to 2.4 basis points, whereas the mean daily returns for the other non-turn-of-the-month days range from -4.1 to 6.7 basis points.

For the January versus other non-turn-of-the-month days effect the patterns present in the indices are reflected in the futures contracts in that no significant results were obtained.

The results obtained for indices in this study differ from those of Hattingh \& Smit (1993) in that no significant results are obtained for the All Share Index and All Industrial Index, whereas these were significant in the earlier study.

\section{Conclusion}

The primary goal for this study is to determine whether known seasonal patterns in the South African share and bond markets also appear in futures contracts. The underlying indices are also examined to determine whether the seasonal patterns in the futures contracts reflect the seasonal patterns in the indices. The following six calendar effects are considered: day-of-the-week or Monday effect; week-of-the-month effect; month-of-the-year or January effect; turn-of-themonth effect; turn-of-the-year effect; and January versus other non-turn-of-the-month days effect.

The All Share Near Future and All Share Index show a significant day-of-the-week, week-of-the-month and turn-of-themonth effect and the patterns obtained in each effect are almost identical for the two groups of data. For the two sets of data identical seasonal patterns are found in the month-of the-year, turn-of-the-year and January versus other non-turnof-the-month days effects, but the results are not significant at the 5\% significance level.

The All Industrial Near Future and All Industrial Index show a significant day-of-the-week and turn-of-the-year effect and the patterns obtained in each effect are almost identical for the two groups of data. The All Industrial Index also shows a significant turn-of-the-month effect, but for the All Industrial Near Future this effect is only significant at the $5.34 \%$ significance level. For the two sets of data very similar seasonal patterns are also found in the week-of-the-month, month-of-the-year and January versus other non-turn-ofthe-month days effects, but the results are not significant at the $5 \%$ significance level. 
The All Gold Near Future and All Gold Index show a significant week-of-the-month effect and the week-of-the-month patterns obtained are identical for the two groups of data. For the two sets of data very similar seasonal patterns are also found in the day-of-the-week effect and identical seasonal patterns are found in the month-of-the-year, turn-of-themonth, turn-of-the-year and January versus other non-turn-ofthe-month days effects, but the results are not significant at the $5 \%$ significance level.

For all the indices investigated the seasonal patterns of the returns present in the data are largely reflected in the futures contracts. This result differs from that of Johnston, Kracaw \& McConnell (1991) in the American futures market, where seasonal patterns established in the cash market for T-bills are not reflected in the corresponding T-bill futures contract.

Finally, the seasonal patterns established in this study correspond very well with the earlier study of Hattingh \& Smit (1993), the main difference being that due to a more limited data base, significant results are more difficult to establish.

\section{Acknowledgement}

The comments of a referee are gratefully acknowledged. The usual disclaimer applies.

\section{References}

Ariel, R.A. 1987. 'A monthly effect in stock returns', Journal of Financial Economics, Vol. 18: 161-174

Bhana, N. 1985. 'The Monday effect on the Johannesburg Stock Exchange', South African Journal of Business Management, Vol. 16: 7-11.

Bradfield, D.J. 1990. 'A note on the seasonality of stock returns on the Johannesburg Stock Exchange', South African Journal of Business Management, Vol. 21: 7-9.

Chang, E.C., Pinegar, J.M. \& Ravichandran, R. 1993. 'International evidence on the robustness of the day-of-the-week effect', Journal of Financial and Quantitative Analysis, Vol. 28: 497-513.

Chang, E. \& Kim, C. 'Day of the week effects and commodity price changes', Journal of Futures Markets, Vol. 8: 229-241.

Chiang, R. \& Tapley, C. 1983. 'Day-of-the-week effects and the futures market', Review of Research in Futures Markets, Vol. 2: $356-410$

Connolly, R.A. 1989. 'An examination of the robustness of the weekend effect', Journal of Financial and Quantitative Analysis, Vol. 24: 133-169.

Connolly, R.A. 1991. 'A posterior odds analysis of the weekend effect', Journal of Econometrics, Vol. 49: 51-104.

Cornell, B. 1985. 'The weekly pattern in stock returns cash versus futures a note', Journal of Finance, Vol. 40: 583-588.
Dyl, E. \& Maberly, E. 1986. 'The weekly pattern in stock index futures a further note', Journal of Finance, Vol. 41: 1149-1155.

French, K.R. 1980. 'Stock returns and the weekend effect', Journal of Financial Economics, Vol. 8: 55-69.

Gay, G. \& Kim, T. 1987. 'An investigation into seasonality in the futures market', Journal of Futures Markets, Vol. 7: 169-181.

Gibbons, M.R. \& Hess, P. 1981. 'Day of the week and asset returns', Journal of Business, Vol. 54, October, 579-596.

Harris, L. 1986. 'A transaction data study of weekly and intradaily patterns in stock returns', Journal of Financial Economics, Vol. 16: 99-117.

Hattingh, F.S. \& Smit, E. v.d. M. 1993. 'Seisoenale patrone in die Suid-Afrikaanse kapitaalmark', South African Journal of Business Management, Vol. 24, No. 4: 142-146.

Johnston, E.T., Kracaw, A. \& Mc Connell, J.J. 1991. 'Day-of-theweek effects in financial futures: an analysis of GNMA, T-Band, T-Note, and T-Bill contracts', Journal of Financial and Quantitative Analysis, Vol. 26: 23-44.

Jordan, S.D. \& Jordan, B.D. 1991. 'Seasonality in daily bond returns', Journal of Financial and Quantitative Analysis, Vol. 26: 269-285.

Jaffee, J. \& Westerfield, R. 1985. 'The weekend effect in common stock returns: the international evidence', Journal of Finance, Vol. 40: 433-454.

Keim, D. \& Stambaugh, R. 1984. 'A further investigation of the weekend effect in stock returns', Journal of Finance, Vol. 39: 813-834.

Lakonishok, J. \& Levi, M. 1982. 'Weekend effects on stock returns: a note', Journal of Finance, Vol. 37: 883-889.

Pettengill, G.N. \& Jordan, B.D. 1988. 'A comprehensive examination of volume effects and seasonality in daily security returns', Journal of Financial Research, Vol. 11: 57-70.

Reinganum, M.R. 1983. 'The anomalous stock market behaviour of small firms in January', Journal of Financial Economics, Vol. 12: 89-104.

Rogalski, R.J. 1984. 'New findings regarding day-of-the-week returns over trading and non-trading periods: a note', Journal of Finance, Vol. 39: 1603-1614.

Rozeff, M.S. \& Kinney, W.R. 1976. 'Capital market seasonality: the case of stock returns', Journal of Financial Economics, Vol. 3: 379-402.

Smirlock M. \& Starks, L. 1986. 'Day-of-the-week and intraday effects in stock returns', Journal of Financial Economics, Vol. 17: 197-210.

Smirlock, M. 1986. 'Seasonality and bond market returns', Journal of Portfolio Management, Vol. 11: 42-44.

Snell, A. \& Smit, E.v.d.M. "The performance of the South African Share Index Futures Market over the period 1987-1989', Journal for Studies in Economics and Econometrics, Vol. 14, No. 3: $37-52$. 